\title{
IL-12-STAT4-IFN- $\gamma$ axis is a key downstream pathway in the development of IL-13-mediated asthma phenotypes in a Th2 type asthma model
}

\author{
You-Sun Kim ${ }^{1}$, Seng-Jin Choi ${ }^{1}$, Jun-Pyo Choi ${ }^{1}$, \\ Seong Gyu Jeon ${ }^{1}$, Sun-Young $\mathrm{Oh}^{2}$, Byung-Jae Lee ${ }^{4}$, \\ Yong Song Gho', Chun Geun Lee ${ }^{3}$, Zhou Zhu', \\ Jack A. Elias ${ }^{3}$ and Yoon-Keun Kim ${ }^{1,5}$ \\ 'Department of Life Science \\ Division of Molecular and Life Sciences \\ Pohang University of Science and Technology (POSTECH) \\ Pohang 790-784, Korea \\ ${ }^{2}$ Division of Allergy and Clinical Immunology \\ Asthma and Allergy Center \\ Johns Hopkins University, MD, USA \\ ${ }^{3}$ Section of Pulmonary and Critical Care Medicine \\ Yale University School of Medicine \\ New Haven, CT, USA \\ ${ }^{4}$ Deparment of Allergy and Clinical Immunology \\ Sungkyunkwan University College of Medicine \\ Seoul 135-710, Korea \\ ${ }^{5}$ Corresponding author:Tel, 82-54-279-2125; \\ Fax, 82-54-279-8449; E-mail, juinea@ postech.ac.kr \\ DOI 10.3858/emm.2010.42.8.054
}

Accepted 30 June 2010

Available Online 1 July 2010

Abbreviations: AHR, airway hyperresponsiveness; BAL, bronchoalveolar lavage; Dox, doxycycline-containing water; LPS, lipopolysaccharide; OVA, ovalbumin; TG, transgenic; WT, wild type

\begin{abstract}
IL-4 and IL-13 are closely related cytokines that are produced by Th2 cells. However, IL-4 and IL-13 have different effects on the development of asthma phenotypes. Here, we evaluated downstream molecular mechanisms involved in the development of Th2 type asthma phenotypes. A murine model of Th2 asthma was used that involved intraperitoneal sensitization with an allergen (ovalbumin) plus alum and then challenge with ovalbumin alone. Asthma phenotypes, including airway-hyperresponsiveness (AHR), lung inflammation, and immunologic parameters were evaluated after allergen challenge in mice deficient in candidate genes. The present study showed that methacholine AHR and lung inflammation developed in allergen-challenged IL-4-deficient mice but not in allergen-challenged
\end{abstract}

IL-13-deficient mice. In addition, the production of OVA-specific IgG2a and IFN- $\gamma$-inducible protein (IP)-10 was also impaired in the absence of IL-13, but not of IL-4. Lung-targeted IFN- $\gamma$ over-expression in the airways enhanced methacholine AHR and non-eosinophilic inflammation; in addition, these asthma phenotypes were impaired in allergen-challenged IFN- $\gamma$-deficient mice. Moreover, AHR, non-eosinophilic inflammation, and IFN- $\gamma$ expression were impaired in allergen-challenged IL-12R $\beta 2$ - and STAT4-deficient mice; however, AHR and non-eosinophilic inflammation were not impaired in allergen-challenged IL-4R $\alpha$-deficient mice, and these phenomena were accompanied by the enhanced expression of IL-12 and IFN- $\gamma$. The present data suggest that IL-13-mediated asthma phenotypes, such as AHR and non-eosinophilic inflammation, in the Th2 type asthma are dependent on the IL-12-STAT4-IFN- $\gamma$ axis, and that these asthma phenotypes are independent of IL-4Ralpha-mediated signaling.

Keywords: asthma; interferon- $\gamma$; interleukin-12; interleukin-13; respiratory hypersensitivity; Th2 cells

\section{Introduction}

Asthma is an increasingly common disease that is characterized by airway hyperresponsiveness (AHR) and chronic inflammation and remodeling (Pueringer and Hunninghake, 1992). AHR, which is an exaggerated bronchoconstrictive response to non-specific agonists (e.g., methacholine), is considered the hallmark physiologic abnormality underlying asthmatic diathesis (Pueringer and Hunninghake, 1992; Weinberger, 1993; Whyte et al., 1993). Much evidence suggests that allergen-specific $\mathrm{CD}^{+}$Th2 cells play essential roles in initiating and generating this abnormality (Robinson et al., 1992; Robinson et al., 1993; Cohn et al., 1997). However, IL-4 and IL-5 cannot completely account for this physiologic response. For example, the AHR seen in allergen-sensitized and allergen-challenged mice is mediated by a $\mathrm{CD}^{+} \mathrm{T}$ cell-dependent, IL-4- and IL-5-independent activation pathway, although both IL-4 and IL-5 induce eosinophil infiltration into the lung (Hogan et al., 1998). In terms of the roles of Th2 cytokines in the 
A

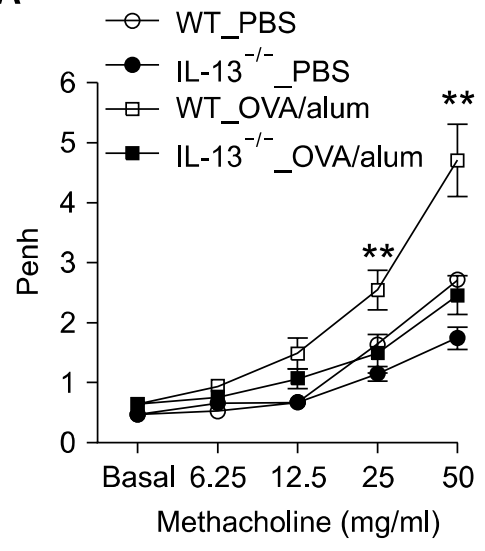

C

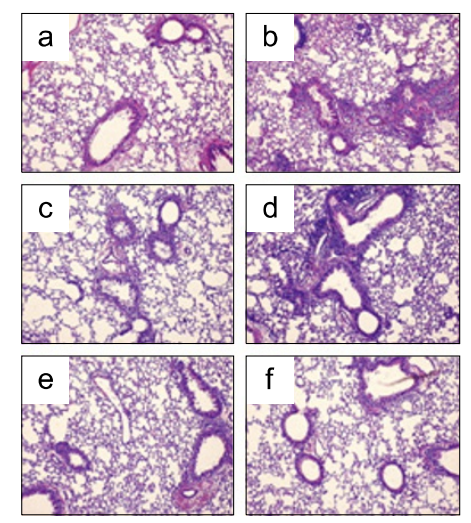

E

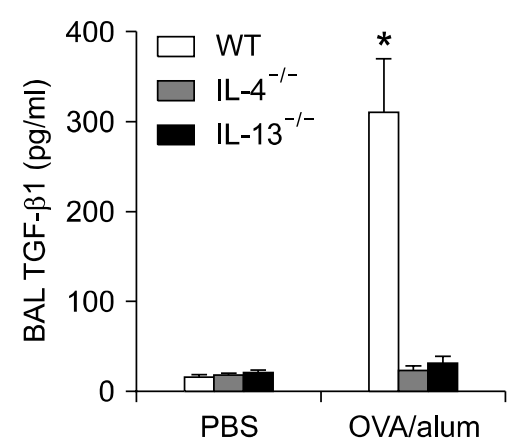

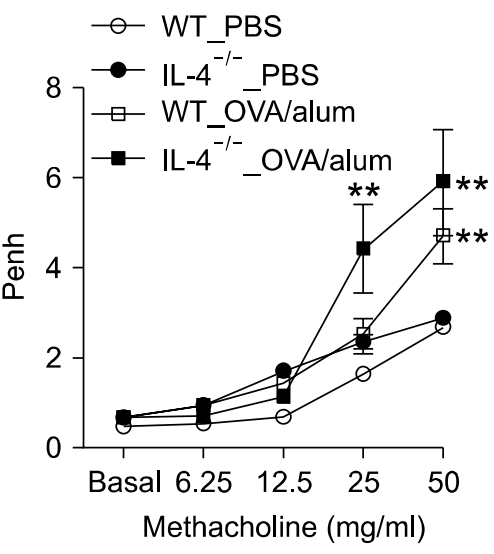

D
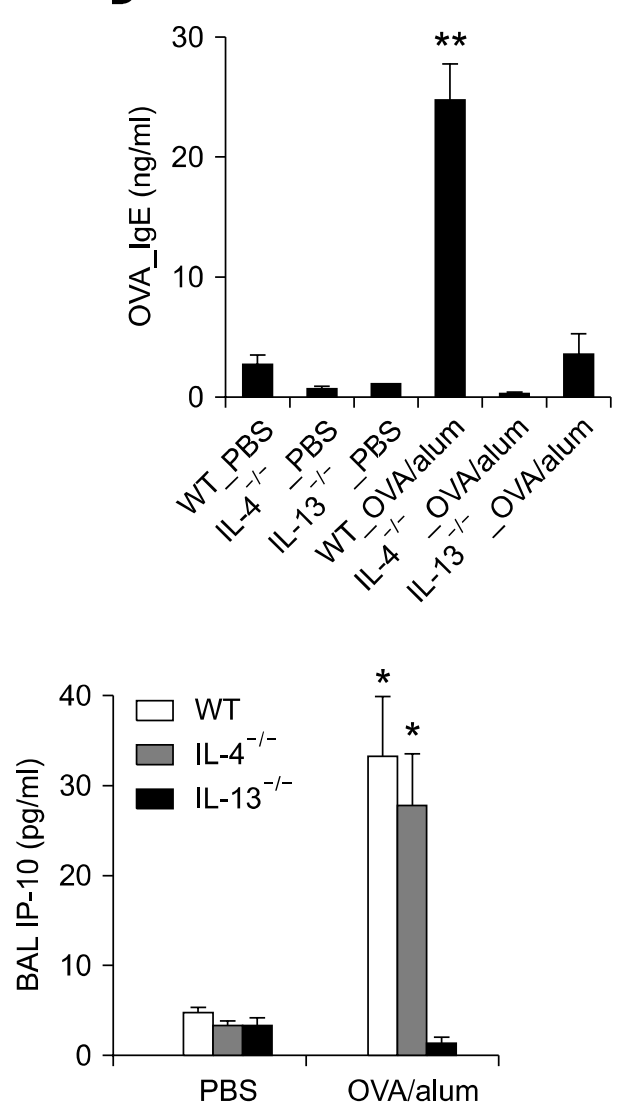
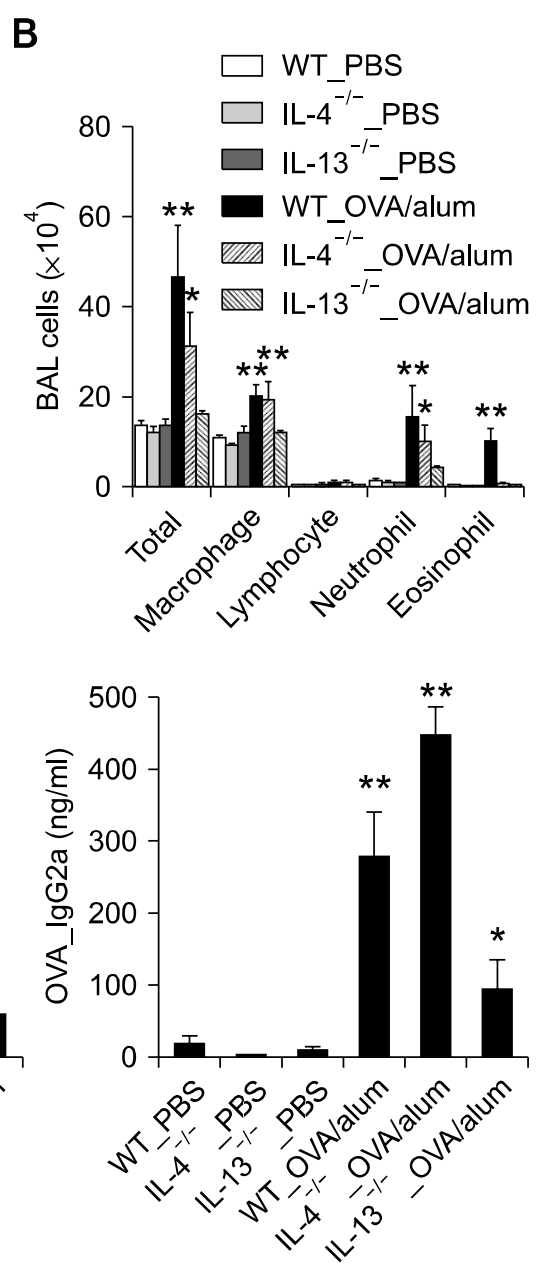

Figure 1. IL-13, but not IL-4, is essential for the development of Th2 type asthma phenotypes. Evaluations ( $n=5$ each group) were performed after allergen challenge. ${ }^{*}, P<0.05$ compared to mice sensitized with PBS; ${ }^{* *}, P<0.05$ versus the other groups. (A) Methacholine AHR $24 \mathrm{~h}$ after the last allergen challenge of IL-13 ${ }^{-1-}$ (left panel), IL-4- (right panel), and the corresponding WT control mice. (B) BAL cellularity $48 \mathrm{~h}$ after the last allergen challenge. (C) Representative lung histology $48 \mathrm{~h}$ after the last allergen challenge (H\&E staining, original magnification $\times 200$ ). a, WT-PBS; b, WT_OVA/alum; c,

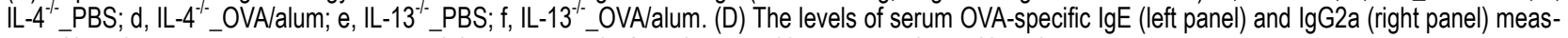
ured $\overline{4} 8 \mathrm{~h}$ after the last allergen challenge. (E) The levels of TGF- $\beta 1$ and IP-10 in the BAL fluids $48 \mathrm{~h}$ after the last allergen challenge.

development of AHR and lung inflammation, IL-13 is now considered to be crucial; blockade of IL-13 markedly inhibits allergen-induced AHR and lung inflammation in a Th2 type allergic asthma model, while IL-13 delivery to the airways rescues these effects (Wills-Karp et al., 1998).

IL-4 and IL-13 are closely related cytokines that are produced in large quantities by activated $\mathrm{CD} 4^{+}$ 
Table 1. Summary of lung infiltration of inflammatory cells after allergen challenge comparing between different genes deficient and wild type control mice.

\begin{tabular}{|c|c|c|c|c|c|c|}
\hline $\begin{array}{c}\text { Ratio } \\
\text { (KO/WT mice) }\end{array}$ & $\mathrm{IL}-4^{-1-}$ & $\mathrm{IL}-13^{-/-}$ & $\mathrm{IFN}-\gamma^{-1-}$ & IL-4R $\alpha^{-/-}$ & IL-12R $\beta 2^{-/-}$ & STAT4 $^{-1-}$ \\
\hline Total cells & $0.67 \pm 0.008$ & $0.35 \pm 0.052$ & $0.39 \pm 0.026$ & $0.57 \pm 0.008$ & $0.60 \pm 0.057$ & $0.37 \pm 0.007$ \\
\hline Macrophages & $0.95 \pm 0.086$ & $0.57 \pm 0.001$ & $0.46 \pm 0.158$ & $0.93 \pm 0.022$ & $0.49 \pm 0.015$ & $0.38 \pm 0.025$ \\
\hline Neutrophils & $0.76 \pm 0.216$ & $0.21 \pm 0.001$ & $0.14 \pm 0.127$ & $1.44 \pm 0.083$ & $0.13 \pm 0.033$ & $0.29 \pm 0.020$ \\
\hline Eosinophils & $0.13 \pm 0.001$ & $0.03 \pm 0.001$ & $0.44 \pm 0.027$ & $0.08 \pm 0.002$ & $0.60 \pm 0.081$ & $0.62 \pm 0.116$ \\
\hline
\end{tabular}

Data are expressed as mean \pm SEM.

Th2 lymphocytes (Kuipers et al., 2003). IL-4 and IL-13 also have overlapping biologic profiles and share the IL-4R $\alpha$ subunit and IL-13R $\alpha 1$ components in their respective multimeric receptor complexes (Murata et al., 1998a; Kuipers et al., 2003). As expected, comparisons of lung-targeted IL-13 and IL-4 transgenic (TG) mice reveal a number of similarities. The transgenes in these mice induce inflammatory responses that are characterized by infiltration of macrophages and significant numbers of eosinophils (Zhu et al., 1999). However, prominent differences between the effects of IL-4 and IL-13 on the development of asthma phenotypes have also been reported. Importantly, IL-4 TG mice do not manifest AHR upon methacholine challenge (Rankin et al., 1996), whereas IL-13 over-expression in the airways induces AHR upon methacholine challenge (Zhu et al., 1999).

The receptor-binding chains for IL-13 include IL-13Ra1 and IL-13Ra2 (Aman et al., 1996; Caput et al., 1996; Hilton et al., 1996; Donaldson et al., 1998). IL-13R 1 binds IL-13 with low affinity. Co-expression of IL-13R $\alpha 1$ with IL-4R $\alpha$ results in the formation of a high-affinity receptor signaling complex (Aman et al., 1996; Hilton et al., 1996; Murata et al., 1998b). This receptor complex is expressed on both lymphoid and non-lymphoid cells and can also be activated by IL-4, which accounts for the overlapping biologic effects of IL-4 and IL-13 (Zurawski et al., 1993). In contrast to IL-13R $\alpha 1$, IL-13R $\alpha 2$ binds selectively to IL-13 with high affinity. The cytoplasmic region of murine IL-13R $\alpha 2$ does not posses an obvious signaling motif (Donaldson et al., 1998). The soluble form of IL-13R 2 has been detected in mouse serum (Zhang et al., 1997), and is similar to the IL-1 type II receptor (Colotta et al., 1995). IL-13Ra2 may function as a decoy to attenuate the effects of the IL-13R $\alpha-I L-4 R \alpha$ receptor complex. However, the production of $\mathrm{IL}-12$, which is related with IFN- $\gamma$ production, was impaired in response to lipopolysaccharide (LPS) in mice deficient for IL-13R $\alpha 2$ $\left(\mathrm{IL}-13 \mathrm{R} \alpha 2^{-1-}\right.$ ) (Wood et al., 2003), suggesting that IL-13R $\alpha 2$-mediated effect is involved in IFN- $\gamma$ production.

In the present study, we hypothesized that the IL-13R $\alpha 2$-mediated pathway is also an important downstream pathway in the development of the IL-13-mediated asthma phenotypes, in addition to IL-4R $\alpha$ - and IL-13R $\alpha 1$ complex-mediated pathway. To test this hypothesis, a murine model of Th2 type allergic asthma was applied to mice deficient in IL-4, IL-13, IL-4R $\alpha$, IL-12R $\beta 2$, STAT4, and IFN- $\gamma$. We also evaluated the effects of high levels of IFN- $\gamma$ in the airways using transgenic approach.

\section{Results}

\section{Expression of allergen-induced methacholine AHR

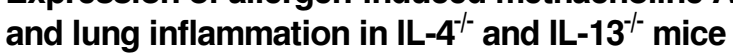

To evaluate the roles of IL- 4 and IL-13 in the development of Th2 type asthma phenotypes, $\mathrm{IL}-4^{-1 /}, \mathrm{IL}-13^{-1 /}$, and age-matched wild type (WT) control (all BALB/c backgrounds) mice were examined in the Th2 asthma mouse model. Methacholine AHR, $24 \mathrm{~h}$ after the final allergen challenge, was significantly lower in $\mathrm{IL}-13^{-1-}$ mice that were sensitized intraperitoneally with ovalbumin (OVA) plus alum than in WT mice that were sensitized in the same manner, whereas it was similar for IL-4- $4^{-1-}$ mice and WT mice sensitized with OVA + alum (Figure 1A). Examination of cellularity in bronchoalveolar lavage (BAL) fluids $48 \mathrm{~h}$ after the final allergen challenge showed that the $\mathrm{IL}-13^{-1-}$ mice sensitized with OVA + alum had not developed allergen challenge-induced inflammation, as compared with WT mice sensitized in the same manner; in contrast, only eosinophilic infiltration was not developed in IL-4 ${ }^{-/ 2}$ mice sensitized with OVA+alum compared to WT mice sensitized in the same manner (Table 1 and Figure 1B). Analyses of lung histology showed that peribronchiolar and perivascular infiltrations of inflammatory cells was similar between IL-13 $3^{-1-}$ mice sensitized with PBS and with OVA+alum, although this phenotype was increased in IL- $4^{-1-}$ or WT control mice sensitized 
A

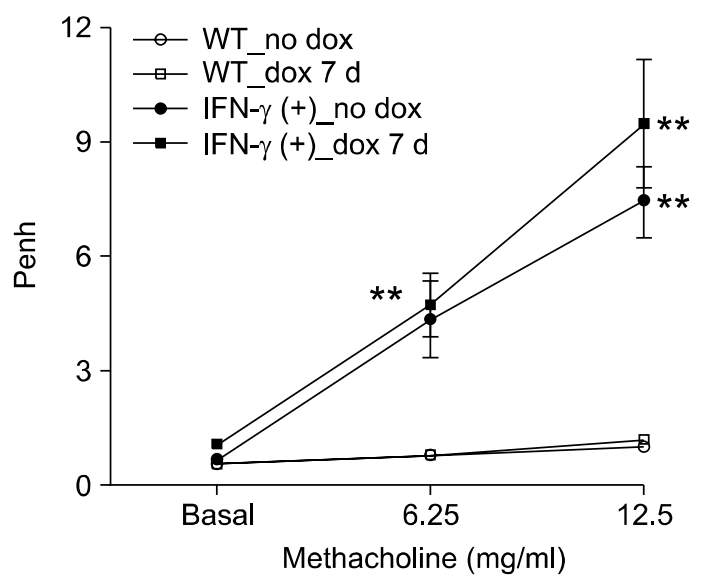

B

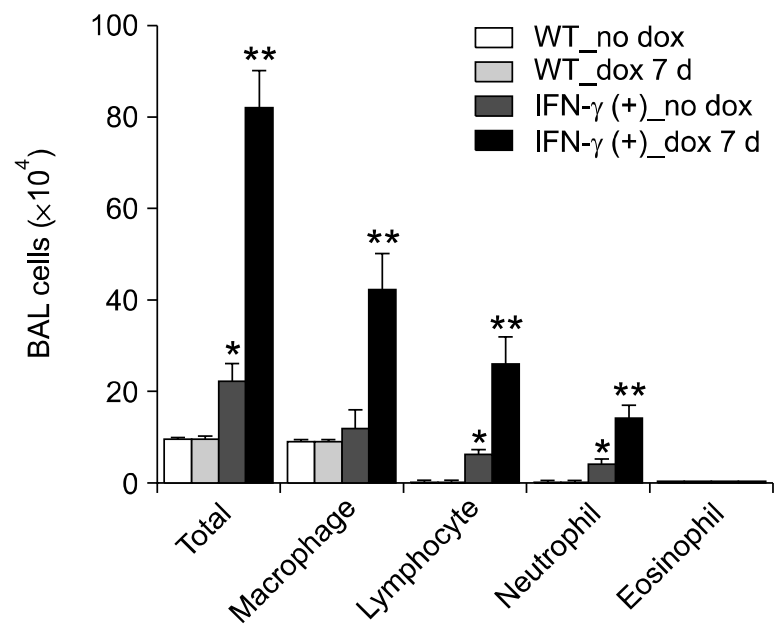

C
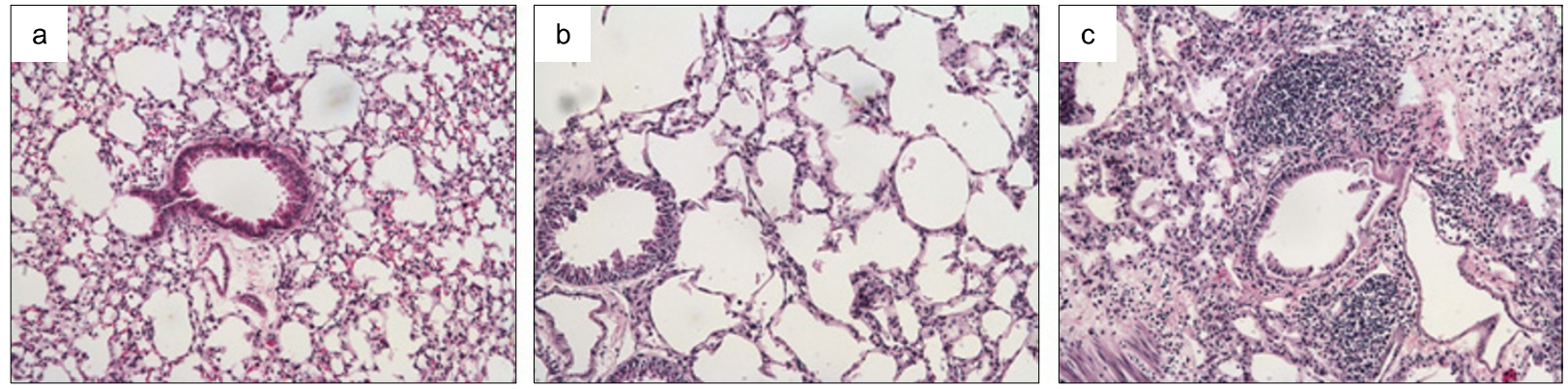

Figure 2. Transgenic over-expression of IFN- $\gamma$ in the airways enhanced methacholine AHR and non-eosinophilic lung inflammation. Evaluations $(n=8$ each group) were performed before and 7 days after the administration of doxycycline-containing water (dox). ${ }^{*}, P<0.05$ compared to littermate WT mice; ${ }^{* *}, P<0.05$ versus the other groups. Methacholine AHR (A) and BAL cellularity (B) before and 7 days after the administration of dox to IFN- $\gamma$ TG mice and their WT control littermates. (C) Representative lung histology (H\&E staining, original magnification $\times 200)$. a, WT_no dox; b, IFN- $\gamma(+) \_n o$ dox; c, IFN- $\gamma(+) \_$dox $7 \mathrm{~d}$.

with OVA+alum, compared to IL-4 ${ }^{-/}$or WT control mice sensitized with PBS, respectively (Figure 1C). In terms of allergen-specific antibody production (Figure 1D), $48 \mathrm{~h}$ after the final allergen challenge, OVA-specific IgE was not found in the sera of either the $\mathrm{IL}-4^{-\gamma-}$ or the $\mathrm{IL}-13^{-1-}$ mice sensitized with OVA+alum. In contrast, the serum levels of OVA-specific IgG2a (a biomarker of Th1 response) were lower in $\mathrm{IL}-13^{-/-}$mice sensitized with OVA+alum than in WT mice sensitized in the same manner, although the corresponding levels were not lower in the $\mathrm{IL}-4^{-/-}$mice sensitized with OVA+alum, as compared to the latter group. We also evaluated the production of Th1- and Th2-downstream mediators $48 \mathrm{~h}$ after the final allergen challenge (Figure 1E). The levels of TGF- $\beta 1$ (a key downstream molecule of Th2 cytokines) in the BAL fluids were significantly lower in both the $\mathrm{IL}-4^{-1-}$ and $\mathrm{IL}-13^{-1-}$ mice that were sensitized with OVA+alum than in the WT mice sensitized in the same manner. In contrast, the levels of IP-10 (a key Th1-downstream molecule) in the BAL fluids were lower in the $\mathrm{IL}-13^{-1-}$ mice sensitized with OVA+alum than in the $\mathrm{IL}-4^{-/-}$and WT mice sensitized in the same manner, while the latter groups had similar levels of IP-10. Taken together, these findings suggest that AHR, non-eosinophilic lung inflammation, and allergen-specific IgG2a production induced by allergen challenge in the Th2 type asthma are dependent upon IL-13-mediated signaling, but not on IL-4-mediated signaling.

\section{AHR and pathologic changes in TG mice with lung-targeted over-expression of IFN- $\gamma$}

To evaluate in vivo effects of IFN- $\gamma$ on lung pathology, pathologic changes were evaluated in 
A

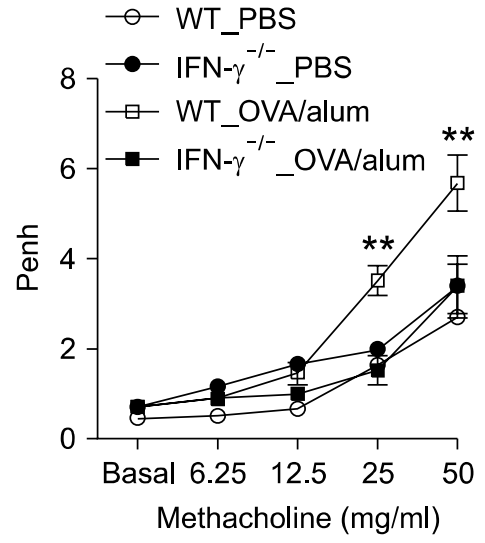

B

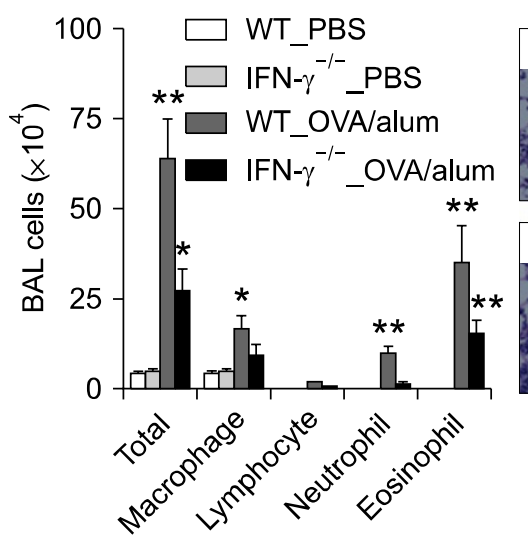

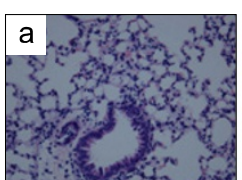
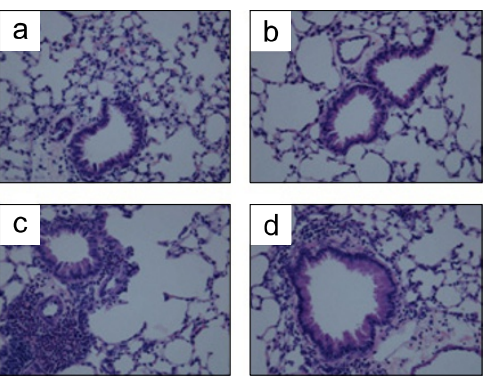

C

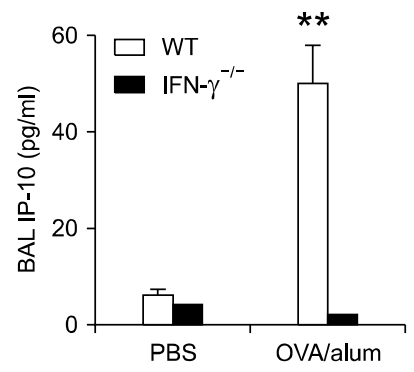

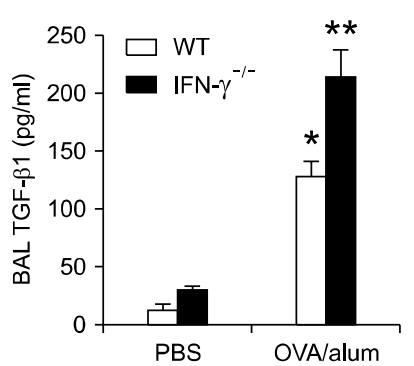

D
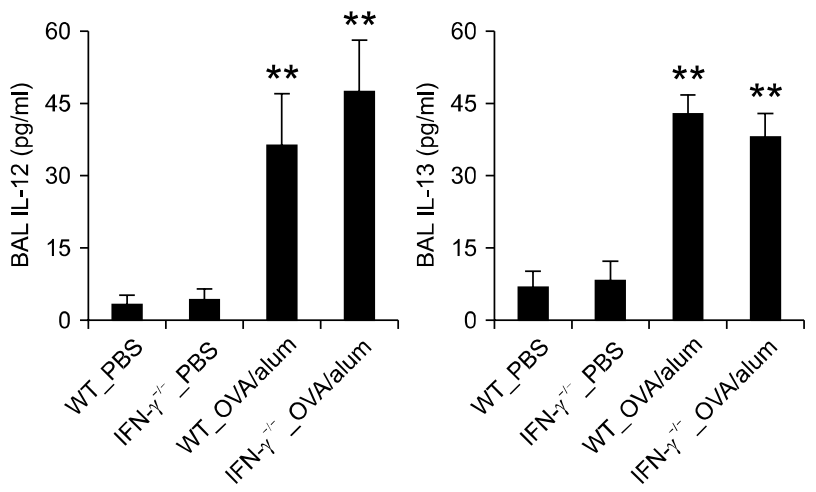

Figure 3. IFN- $\gamma$ plays key roles in the development of AHR and non-eosinophilic lung inflammation in the murine model of Th2 type asthma. For all figures, evaluation ( $n=5$ each group) was performed after allergen challenge. ${ }^{*}, P<0.05$ compared to mice sensitized with PBS; ${ }^{* *}, P<0.05$ versus the other groups. (A) Methacholine AHR in IFN- $\gamma^{-1-}$ and WT (BALB/c) mice $24 \mathrm{~h}$ after the last allergen challenge. (B) BAL cellularity (left panel) and representative lung histology in IFN- $\gamma^{--}$and WT (BALB/c) mice $48 \mathrm{~h}$ after the last allergen challenge. (H\&E staining, original magnification $\times 400$ ). $a$, WT_PBS; $b$, IFN- $\gamma^{-1} \_$PBS; c, WT_OVA/alum; d, IFN- $\gamma^{-I_{-}}$OVA/alum. (C) BAL IP-10 (left panel) and TGF- $\beta 1$ (right panel) levels in IFN- $\gamma^{-f_{-}}$and WT control mice $48 \mathrm{~h}$ after the last allergen challenge. (D) BAL IL-12 (left panel) and IL-13 (right panel) levels in IFN- $\gamma^{-1}$ and WT control mice $6 \mathrm{~h}$ after three rounds of allergen challenge.

TG (BALB/c) mice with lung-targeted inducible IFN- $\gamma$ over-expression and littermate WT control (BALB/c) mice, before and 7 days after the administration of doxycycline-containing water (dox). Methacholine AHR was significantly enhanced in the IFN- $\gamma$ TG (+) mice both before and 7 days after dox, as compared to the littermate WT mice before and 7 days after dox treatment (Figure 2A). BAL cellularity measurements showed that infiltration into the lungs of macrophages, lymphocytes, and neutrophils, but not of eosinophils, was markedly enhanced in the IFN- $\gamma$ TG (+) mice 7 days after dox treatment, as compared to the other groups, although infiltration of these cells was enhanced in the IFN- $\gamma$ TG (+) mice before dox treatment, as compared to WT mice (Figure 2B). Lung histology also showed that peribronchiolar and perivascular infiltration of inflammatory cells was markedly increased in IFN- $\gamma$ TG (+) mice $7 \mathrm{~d}$ after dox, compared to the other groups; in addition, emphysematous changes in the parenchyma was noted in both IFN- $\gamma$ TG (+) mice before and $7 \mathrm{~d}$ after dox (Figure $3 \mathrm{C}$ ). These findings together suggest that over-expression of IFN- $\gamma$ in the lung induces not only emphysema, but also asthma that is characteristic of non-eosinophilic subtype.

\section{The role of IFN- $\gamma$ in the development of allergen-induced Th2 asthma phenotypes}

To evaluate the roles of IFN- $\gamma$ in the expression of asthma phenotypes, the murine model of Th2 type asthma was applied to IFN- $\gamma^{-/-}$and age-matched WT control (BALB/c) mice, with evaluation after 
A
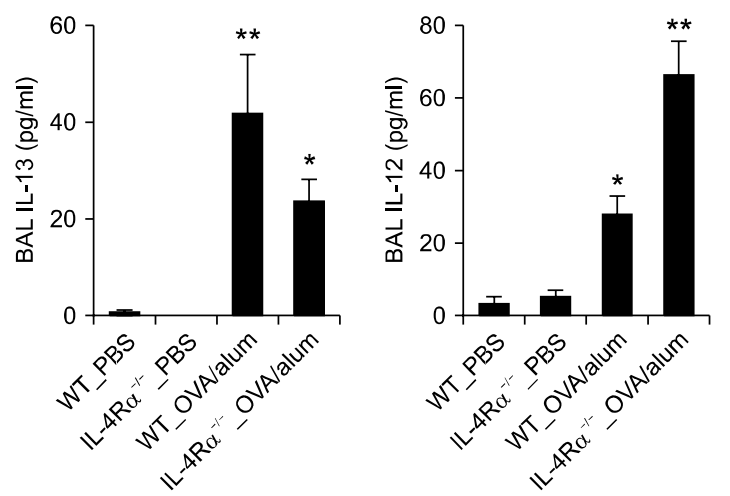

B

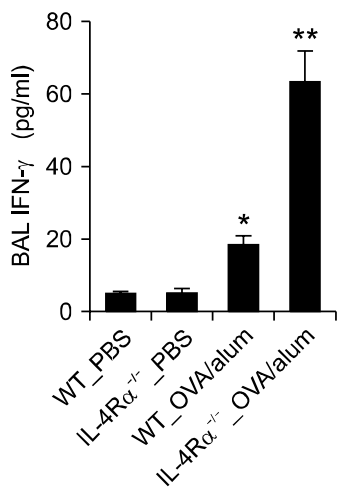

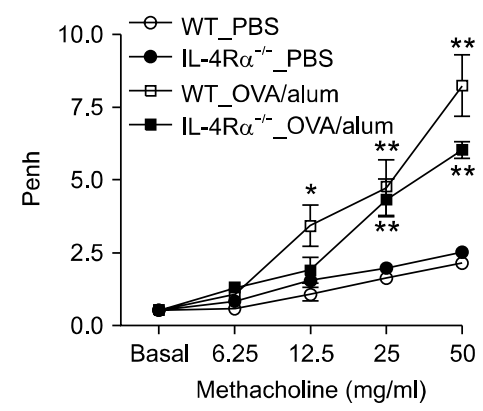

C

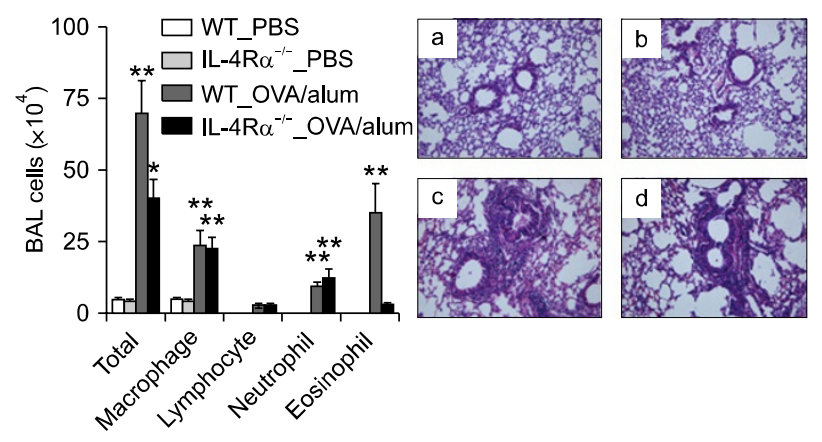

D

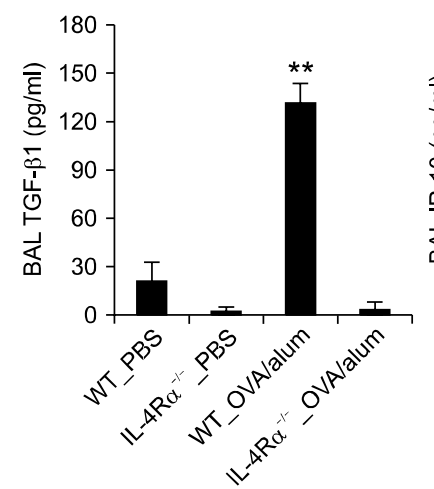

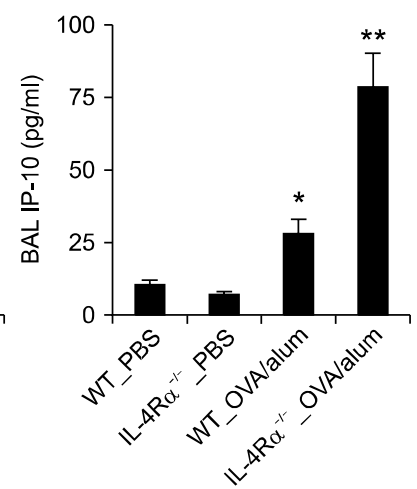

Figure 4. AHR and non-eosinophilic lung inflammation are not impaired by the absence of IL-4R $\alpha$-mediated signaling in the Th2 asthma model. Evaluations ( $n=5$ each group) were performed twice after allergen challenge. ${ }^{*}, P<0.05$ compared to mice sensitized with PBS; ${ }^{*}, P<0.05$ versus the other groups. (A) Levels of cytokines in the BAL fluids of the IL-4Ro ${ }^{-1-}$ and WT (BALB/C) mice $6 \mathrm{~h}$ after three rounds of allergen challenge. (B) Methacholine AHR $24 \mathrm{~h}$ after the final allergen challenge. (C) BAL cellularity (left panel) and representative lung histology (right panel) in IL-4R $\alpha^{-1-}$ and WT mice $48 \mathrm{~h}$ after the final allergen challenge. (H\&E staining, original magnification $\times 200$ ). a, WT_PBS; $b, I L-4 R \alpha^{--}$PPBS; c, WT_OVA/alum; d, IL-4R $\alpha^{-1-}$ OVA/alum. (D) Levels of TGF- $\beta 1$ (upper panel) and IP-10 (lower panel) $48 \mathrm{~h}$ after the final allergen challenge.

allergen challenge. Methacholine AHR $24 \mathrm{~h}$ after allergen challenge was significantly lower in the IFN- $\gamma^{-/}$mice sensitized with OVA+alum than in the WT mice sensitized in the same manner (Figure $3 A)$. Assessment of BAL cellularity and lung histology $48 \mathrm{~h}$ after allergen challenge revealed that lung inflammation was lower in the IFN- $\gamma^{-/-}$ mice sensitized with OVA+alum than in the WT mice sensitized in the same manner; in particular, lung infiltration of inflammatory cells other than eosinophils was decreased in the former group, as compared to the latter group (Table 1 and Figure 3B). In terms of the production of Th1- and Th2-downstream pro-inflammatory mediators $48 \mathrm{~h}$ after allergen challenge, the production of IP-10 was impaired in IFN- $\gamma^{-1-}$ mice sensitized with OVA+alum, but not in WT mice sensitized in the same manner, whereas the production of TGF- $\beta 1$ was enhanced in the former group, as compared to the latter group (Figure 3C). Next, we evaluated the role of IFN- $\gamma$ in the early production of cytokines after allergen challenge. Thus, the Th2 asthma model was applied to IFN- $\gamma^{-1-}$ and WT control $(B A L B / c)$ mice and the levels of cytokines were measured $6 \mathrm{~h}$ after three rounds of allergen challenge. The levels of $\mathrm{IL}-12$ and IL-13 were similar for the IFN- $\gamma^{-1}$ and WT mice sensitized with OVA+alum (Figure 3D). Even though IP-10 production was enhanced by sensitization with OVA+alum in the WT mice, it was completely impaired in the IFN- $\gamma^{-1-}$ mice (data not shown). These findings together suggest that allergen-induced AHR and lung infiltration of inflammatory cells other than eosinophils are dependent upon IFN- $\gamma$-mediated signaling, and that both IL-12 and IL-13 are produced as upstream cytokines of IFN- $\gamma$ following allergen challenge in the Th2 type asthma model. 
A

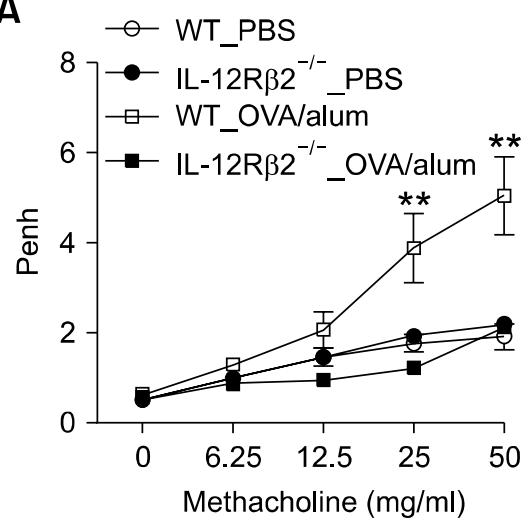

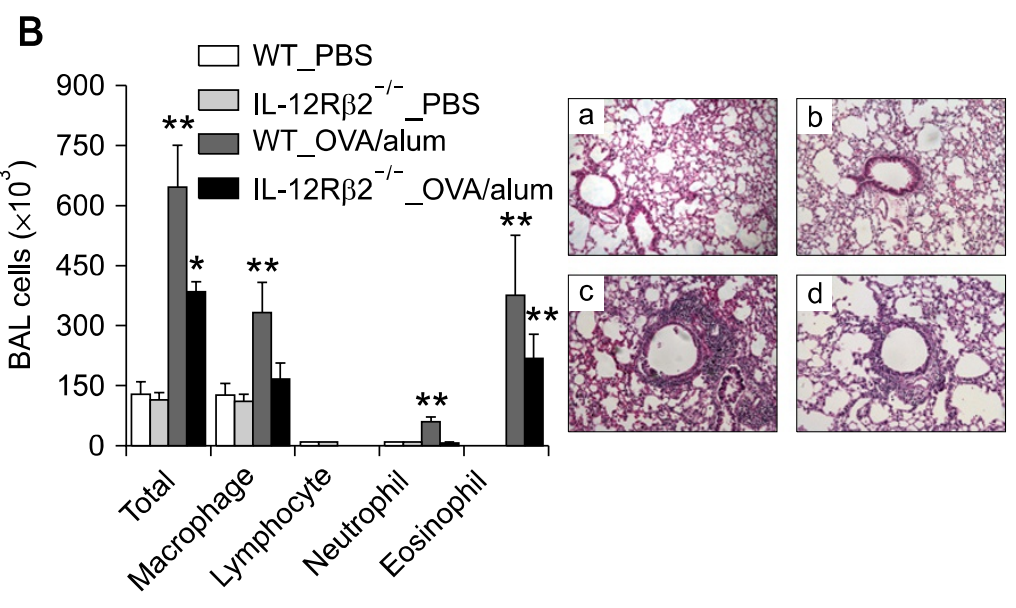

C

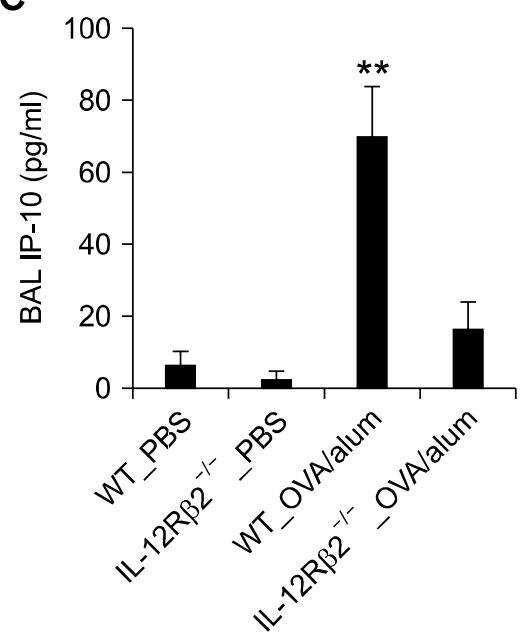

E

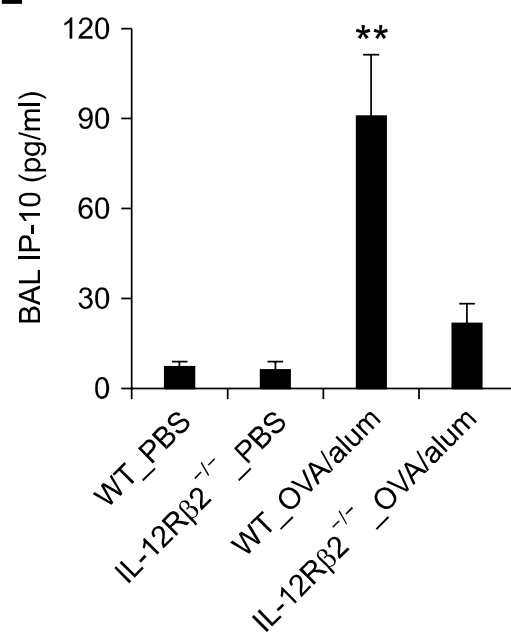

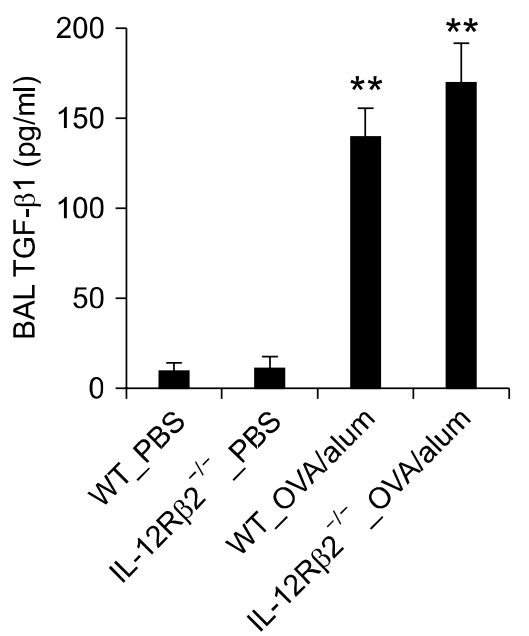

D

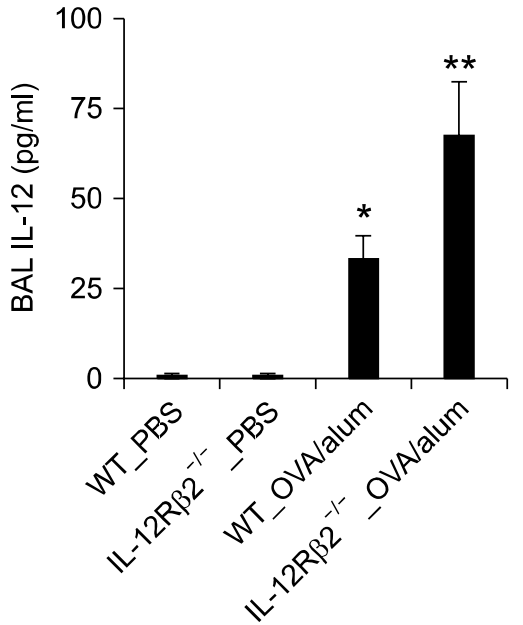

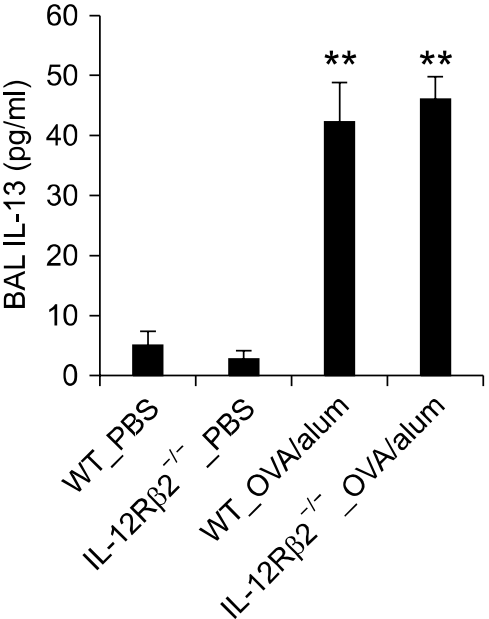

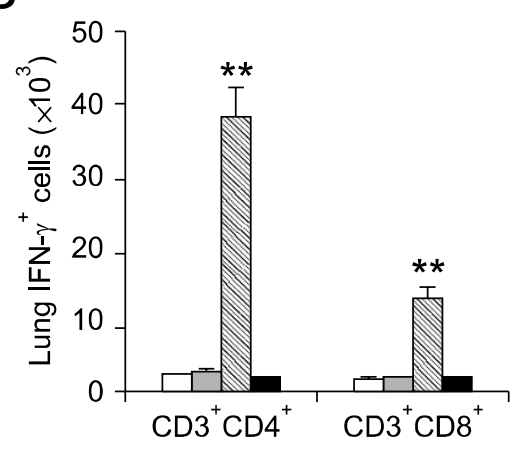

Figure 5. AHR and non-eosinophilic lung inflammation are impaired by the absence of IL-12R $\beta 2$-mediated signaling in the Th2 asthma model. Evaluations ( $n=5$ each group) were performed twice after allergen challenge. ${ }^{*}, P<0.05$ compared to mice sensitized with PBS; ${ }^{*}, P<0.05$ versus the other groups. (A) Methacholine AHR of IL-12R $32^{-/-}$and WT (C57BL/6) mice $24 \mathrm{~h}$ after the final allergen challenge. (B) BAL cellularity (left panel) and representative lung histology $48 \mathrm{~h}$ after the final allergen challenge. (H\&E staining, original magnification $\times 200$ ). a, WT_PBS; b, IL-12R $\beta 2^{-1-}$ PBS; c, WT_OVA/alum; d, IL-12R $\beta 2^{-1 /}$ OVA/alum. (C) The levels of IP-10 (left panel) and TGF- $\beta 1$ (right panel) in the BAL fluids of IL-12R $\beta 2^{-1-}$ and WT mice $6 \mathrm{~h}$ after three rounds of allergen challenge. (D) IFN- $\gamma$-producing CD4+ and CD8+ T cells in IL-12R $\beta 2^{--}$and WT mice $6 \mathrm{~h}$ after three rounds of allergen challenge. (E) Levels of IP-10 (left panel), IL-12 (middle panel), and TGF- $\beta 1$ (right panel) in the IL-12R $\beta 2^{-/-}$and WT mice $48 \mathrm{~h}$ after the final allergen challenge. 


\section{Allergen-induced AHR and lung inflammation in the absence of IL-4R $\alpha$-mediated signaling}

To evaluate the role of IL-4R $\alpha$-mediated signaling in the early production of cytokines after allergen challenge, the Th2 asthma model was applied to IL-4R $\alpha^{-1-}$ and WT control (BALB/C) mice, which were evaluated $6 \mathrm{~h}$ after allergen challenge. The production of IL-13 was not completely abolished in IL-4Ra $\alpha^{-l-}$ mice that were sensitized with OVA+alum, as compared to those sensitized with PBS alone; in addition, the production of IL-12 induced by sensitization with OVA+alum was increased in $\mathrm{IL}-4 \mathrm{Ra}^{-/-}$mice, as compared to WT mice; moreover, the BAL IFN- $\gamma$ levels were increased to a greater extent in the IL-4Ro ${ }^{-/-}$mice sensitized with OVA+alum than in the WT mice sensitized with OVA+alum (Figure 4A). These findings suggest that the production of IFN- $\gamma$ after allergen challenge is enhanced in the absence of IL-4R $\alpha$-mediated signaling in the Th2 asthma model.

We also evaluated the role of IL-4R $\alpha$-mediated signaling in the development of Th2 asthma phenotypes, the asthma model was applied to IL-4R $\alpha^{-/-}$and WT control (BALB/c) mice, and AHR and inflammation were evaluated $24 \mathrm{~h}$ and $48 \mathrm{~h}$, respectively, after the final allergen challenge. Methacholine AHR enhanced by allergen sensitization was not altered in the IL- $4 \mathrm{R}^{-{ }^{-/}}$mice compared to the WT mice (Figure 4B). In addition, BAL cellularity and lung histology showed that only eosinophilic infiltration was impaired in the IL-4R $\alpha^{-1-}$ mice sensitized with OVA+alum, as compared to WT mice sensitized in the same manner, although the levels of lung infiltration of inflammatory cells other than eosinophils were similar for these two groups (Table 1 and Figure 4C). Regarding the production of Th1- and Th2-downstream mediators, the production of TGF- $\beta 1$ was completely impaired in IL-4Ro $\alpha^{-l-}$ mice that were sensitized with OVA+alum, as compared with WT mice sensitized in the same manner; however, the production of IP-10 was enhanced in the former group, as compared to the latter group (Figure 4D). Taken together, these findings suggest that AHR and non-eosinophilic inflammation are independent of IL-4R $\alpha$-mediated signaling, whereas lung infiltration of eosinophils is dependent upon this signaling.

\section{The role of IL-12R $\beta 2$-mediated signaling in the development of allergen-induced AHR and lung inflammation}

To evaluate the role of IL-12R-mediated signaling in the development of Th2 asthma phenotypes, the murine model of Th2 asthma was applied to
IL-12R $\beta 2^{-/-}$and age-matched WT control (C57BL/6) mice. Methacholine AHR $24 \mathrm{~h}$ after the final allergen challenge was impaired in the IL-12R $\beta 2^{-1-}$ mice sensitized with OVA+alum, as compared with the WT mice sensitized in the same manner (Figure $5 \mathrm{~A}$ ). In addition, evaluation of BAL cellularity and lung histology $48 \mathrm{~h}$ after allergen challenge showed that lung infiltration of macrophages and neutrophils, but not eosinophils, was also impaired in the former group, as compared with the latter group (Table 1 and Figure 5B). These changes in asthma phenotypes were accompanied by down-regulation of IP-10 production, but not of TGF- $\beta 1$ production (Figure $5 \mathrm{C}$ ). We also evaluated the role of IL-12R $\beta 2$-mediated signaling on the production of IFN- $\gamma$ after allergen challenge. We found that lung infiltration of IFN- $\gamma$-producing $\mathrm{CD} 4^{+}$and $\mathrm{CD} 8^{+} \mathrm{T}$ cells $6 \mathrm{~h}$ after allergen challenge was impaired in IL-12R $\beta 2^{-/-}$ mice sensitized with OVA+alum, as compared to WT mice sensitized with OVA+alum (Figure 5D). Similarly, production of the IFN- $\gamma$-downstream mediator IP-10 was impaired in the former group, as compared with the latter group, whereas the production levels of IL-12 and IL-13 were not impaired in these two groups (Figure 5E). These findings together suggest that IL-12R $\beta 2$-mediated signaling is important for the development of AHR and lung infiltration of inflammatory cells except eosinophils, and that the expression of IFN- $\gamma$ after allergen challenge is mainly dependent upon IL-12R $\beta 2$-mediated signaling.

\section{The role of STAT4 signaling in the development of Th2 asthma phenotypes}

Given the evidence that IL-12 up-regulates IFN- $\gamma$ production mainly via the STAT4 signaling pathway (Szabo et al., 2003), we evaluated the role of STAT4 signaling pathway in the development of Th2 asthma phenotypes. Thus, the murine model of asthma was applied to STAT4 ${ }^{-1-}$ and age-matched WT control (BALB/c) mice. We found that methacholine AHR $24 \mathrm{~h}$ after the final allergen challenge was impaired in the STAT4 ${ }^{-1}$ mice sensitized with OVA+alum, as compared with the WT mice sensitized with OVA + alum (Figure 6A). Moreover, evaluation of BAL cellularity and lung histology $48 \mathrm{~h}$ after allergen challenge showed that lung infiltration of inflammatory cells other than eosinophils was impaired in the former group, as compared to the latter group (Table 1 and Figure $6 \mathrm{~B})$. In terms of the production of IL-13 and its downstream mediators in the absence of STAT4-mediated signaling, the production levels of IL-13 and TGF- $\beta 1$ evaluated $48 \mathrm{~h}$ after allergen 


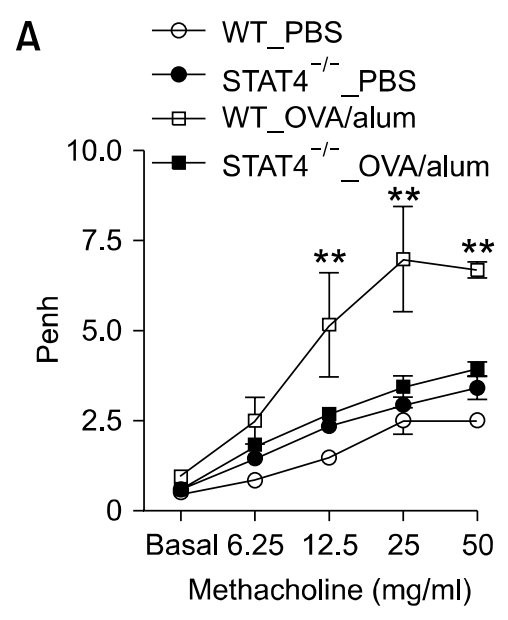

B
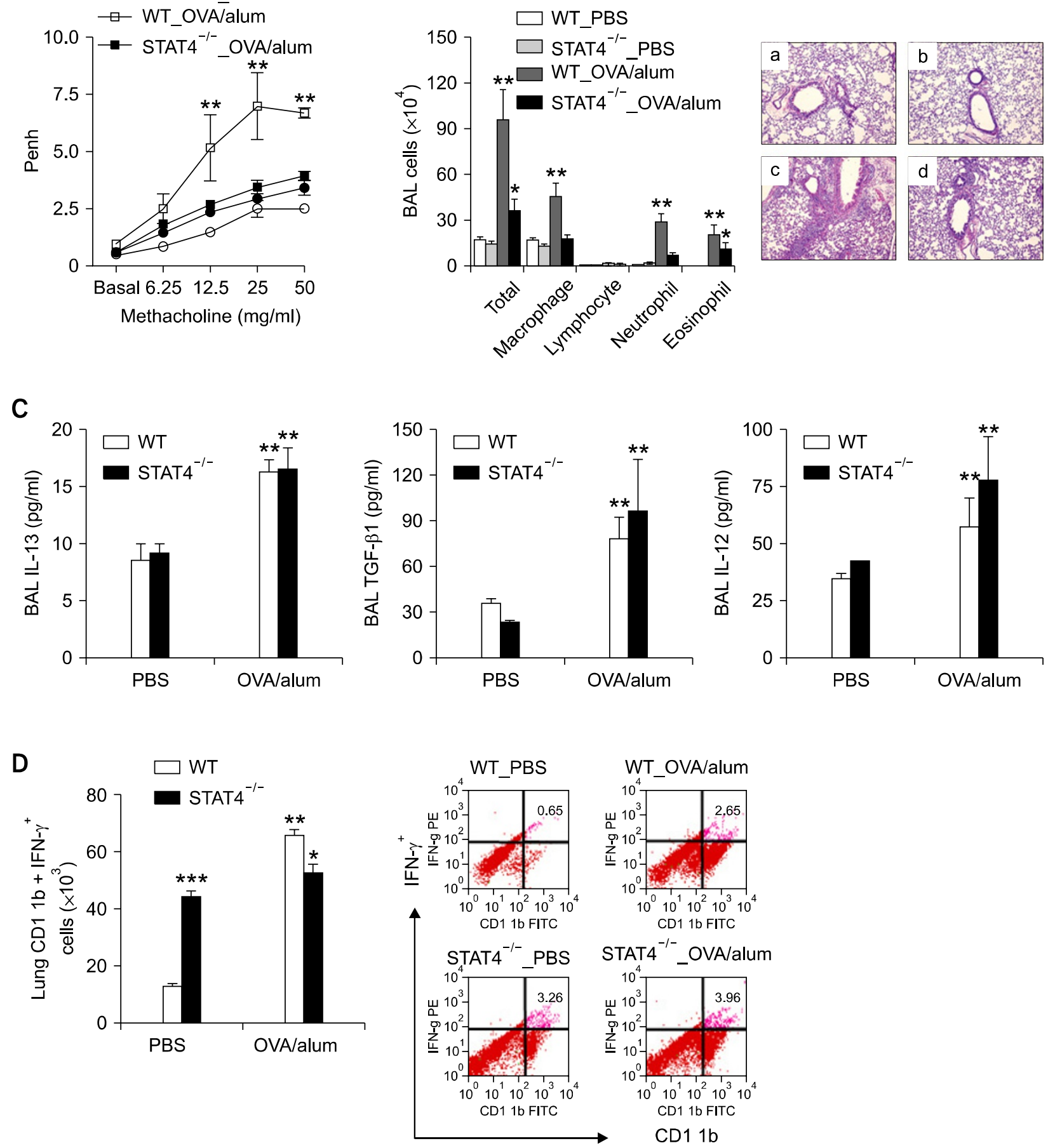

Figure 6. STAT4-mediated signaling plays a key role in the development of AHR and non-eosinophilic inflammation in the Th2 asthma model. Evaluations ( $n=5$ each group) were performed twice $48 \mathrm{~h}$ after the final allergen challenge. ${ }^{*}, P<0.05$ compared to mice sensitized with PBS; ${ }^{* *}, P<0.05$ versus the other groups; ${ }^{* *}, P<0.05$ versus the WT_PBS group. Methacholine AHR (A) and BAL cellularity (B) in STAT4 ${ }^{-*}$ and WT (BALB/c) mice. (H\&E staining, original magnification $\times 100$ ). a, WT_PBS; $b$, STAT4 ${ }^{-1}$ PBS; c, WT_OVA/alum; d, STAT4 ${ }^{-1}$ _OVA/alum. (C) Levels of IL-13 (upper left panel), TGF- $\beta 1$ (upper right panel), and IL-12 (lower panel) in the STAT4 ${ }^{---}$and WT control mice. (D) IFN- $\gamma$-producing CD11b+ cells in the lungs of the STAT4 ${ }^{--}$and WT control mice. 
challenge were similar for the STAT4 ${ }^{-/-}$and WT control mice sensitized with OVA+alum (Figure $6 \mathrm{C})$. Moreover, the IL-12 production levels were similar in these two groups (Figure 6D). However, lung infiltration of IFN- $\gamma$-producing $C D 11 b+$ cells, which was evaluated $48 \mathrm{~h}$ after allergen challenge, was not enhanced by allergen sensitization in the $\mathrm{STAT}^{-/-}$mice, even though it was enhanced in the WT mice (Figure 6E). Taken together, these findings indicate that STAT4-mediated signaling is important for the production of the IFN- $\gamma$ induced by IL-12, as well as for the subsequent development of AHR and infiltration of the lungs by inflammatory cells other than eosinophils.

\section{Discussion}

In the present study, using a murine model of Th2 type asthma, we focused on downstream molecular mechanisms for the development of AHR and lung inflammation and demonstrate that allergen-induced AHR and inflammation are completely dependent upon IL-13, whereas only lung infiltration by eosinophils is dependent upon IL-4 and IL-4R $\alpha$-mediated signaling. These findings suggest that $A H R$ and lung infiltration of inflammatory cells other than eosinophils are mediated by $\mathrm{IL}-13$ and receptor(s) thereof, excluding IL-4 and IL-4R $\alpha$ axis.

AHR is a cardinal feature of asthma and methacholine AHR challenge is frequently used to establish the diagnosis of asthma when clinical uncertainty exists (Pueringer and Hunninghake, 1992; Weinberger, 1993; Whyte et al., 1993). In terms of possible determinants of AHR expression, AHR can be determined by enhancing some phenotypes, e.g., increased hyperplasia and contractility of myofibroblasts or smooth muscle cells, and by inhibiting other phenotypes, e.g., subepithelial and lung parenchymal fibrosis (Hargreave et al., 1986). It is generally accepted that AHR may be related to the inflammation occurring in the asthmatic airways (Weinberger, 1993), although the mechanisms by which asthmatic inflammation leads to AHR are poorly understood. Cohn et al. demonstrated that in vitro-polarized and passively transferred Th2 cells induce AHR in otherwise naive animals via an IL-4-independent pathway (Cohn et al., 1998). Hogan et al. also demonstrated that the AHR seen in allergen-challenged mice is mediated via an IL-4- and IL-5-independent activation pathway (Hogan et al., 1998). In terms of downstream mediators of Th2 cytokines, lung-targeted IL-4 TG and IL-13 TG mice develop subepithelial and lung parenchymal fibrosis, mainly via TGF $\beta 1$-dependent pathways (Rankin et al.,
1996; Lee et al., 2001). TGF $\beta 1$ is a key participant in wound healing and in phenotypic switching from fibroblast to myofibroblast (Morishima et al., 2001). Myofibroblasts are believed to participate in lung fibrosis in asthma and may be more active in terms of producing collagen than resting fibroblasts (Vignola et al., 1997). Interestingly, our previous studies indicate that over-expression of TGF- $\beta 1$ in the airways inhibits $A H R$, which is related with lung fibrosis induced by high levels of TGF- $\beta 1$ in the airways (Jeon et al., 2007a). In the present study, we show that eosinophilic infiltration is dependent upon IL-4- and IL-4R $\alpha$-mediated signaling, which is related with TGF- $\beta 1$ production; however, AHR and lung infiltration of inflammatory cells other than eosinophils are independent of this signaling. These findings suggest that eosinophilic inflammation is not essential in the development of AHR, and that IL-13-mediated AHR is related with lung infiltration of inflammatory cells other than eosinophils via signaling that is mediated by pathway(s) other than IL-4R $\alpha$ and TGF- $\beta 1$.

Previously acquired evidence indicates that IFN- $\gamma$ inhibits allergen-induced eosinophil recruitment into murine lung tissues and is a potent inhibitor of the biologic effects of TGF- $\beta 1$ (Iwamoto et al., 1993). In our previous study, we have shown that airway sensitization with LPS-containing allergens induces non-eosinophilic asthma phenotypes, which are partly dependent upon IFN- $\gamma$ (Kim et al., 2007). Moreover, airway sensitization with allergen plus double-stranded (ds) RNA also induces the non-eosinophilic asthma phenotypes, which are dependent on IFN- $\gamma$ (Jeon et al., 2007b). The present study shows that IFN- $\gamma$ over-expression in the airways also induces the non-eosinophilic inflammation and emphysematous change that are accompanied by enhanced AHR and minimal lung fibrosis. Interestingly, we found that IFN- $\gamma$ was a downstream mediator of IL-13, but not of IL-4- or IL-4R $\alpha$-mediated signaling in the murine model of Th2 asthma. In addition, IL-13-mediated AHR and lung infiltration of inflammatory cells other than eosinophils were related with IFN- $\gamma$-mediated pathway. These findings raise the possibility that IL-13 induces the non-eosinophilic asthma phenotypes via IFN- $\gamma$-mediated effects.

The IL-12 produced by antigen-presenting cells is an important regulator of Th1 cell development (Gavett et al., 1995; Wills-Karp, 1999; Neurath et al., 2002). In a previous study, we showed that non-eosinophilic asthma phenotypes induced by LPS-containing allergens is mediated by the IL-12-STAT4-IFN- $\gamma$ axis (Kim et al., 2007). Previous studies have also shown that IL-12 production is enhanced in the tissue macrophages of IL-13R $\alpha 2^{-/-}$ 


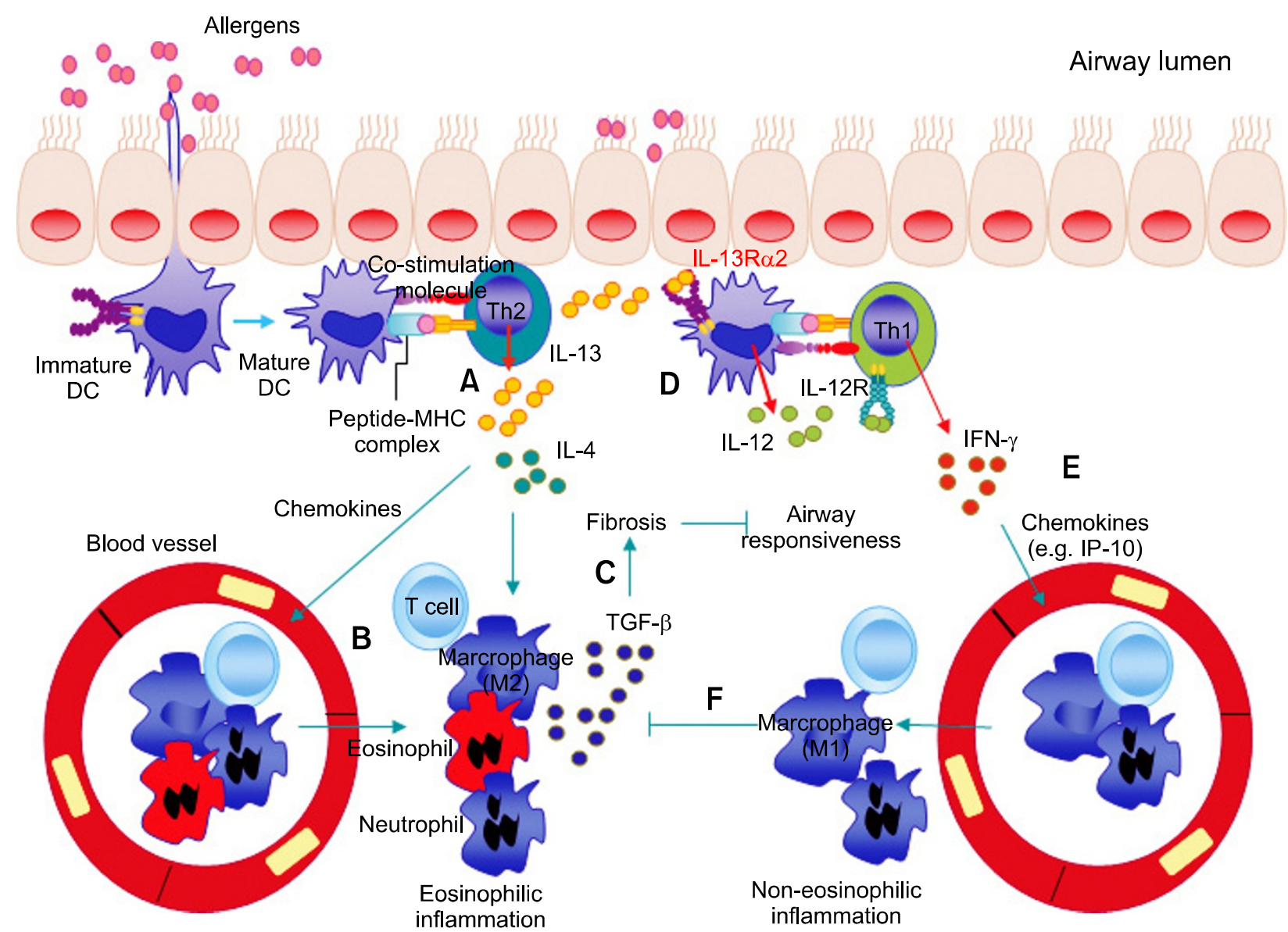

Figure 7. Hypothetical scheme for the development of Th2 type asthma phenotypes. When allergens are inhaled, airway dendritic cells (DCs) present allergens to effector Th2 cells, which produce cytokines, such as IL-4 and IL-13 (A). These cytokines induce lung infiltration of inflammatory cells, including eosinophils (eosinophilic inflammation), via chemokine actions (B). Recruited macrophages (M2 phenotype) and eosinophils produce TGF- $\beta$, which induces lung fibrosis and inhibits airway hyperresponsiveness (C). IL-13 also induces the production of IL-12 from DCs, possibly via IL-13Ra2-mediated signaling, and effector Th1 cells are generated via the IL-12-IL-12Rß2-STAT4-mediated pathway (D). IFN- $\gamma$ produced by effector Th1 cells induces lung infiltration of inflammatory cells other than eosinophils (non-eosinophilic inflammation) via chemokine actions (E). Recruited macrophages (M1 phenotype) produce mediators that inhibit the action of TGF- $\beta$, which results in the enhancement of airway hyperresponsiveness (F).

mice, as compared to WT mice (Wood et al., 2003). Our present study reveals that AHR and lung infiltration of inflammatory cells other than eosinophils are impaired in IL-12R $\beta 2^{-/-}$and STAT4 ${ }^{-/-}$ mice in the Th2 type asthma model, as compared to WT mice. These findings suggest that AHR and lung infiltration of inflammatory cells other than eosinophils induced by IL-13 are dependent upon IL-12-IL-12Rß32-STAT4-mediated signaling, and that IL-13 might induce the production of IL-12 in antigen-presenting cells, possibly via IL-13R $\alpha 2-m e-$ diated signaling.

Taken the previous and present data into consideration, we propose a model for the pathophysiology of IL-13-mediated Th2 asthma phenotypes as shown in Figure 7. When allergens are inhaled, airway dendritic cells (DCs) present the allergens to effector memory Th2 cells, which produce Th2 cytokines, including IL-4 and IL-13. These cytokines induce infiltration into the lungs of inflammatory cells, including eosinophils (eosinophilic inflammation), through the actions of Th2 chemokines. Recruited macrophages (M2 phenotype) and eosinophils produce TGF- $\beta$, which induces lung fibrosis and subsequently inhibits airway hyperresponsiveness. IL-13 also induces the production of IL-12 from DCs, possibly via IL-13R 2 -mediated signaling, especially in situations deficient in IL-4R $\alpha$-mediated signaling. The IFN- $\gamma$ produced from effector Th1 cells via the IL-12-STAT4-IFN- $\gamma$ axis induces lung infiltration of inflammatory cells other than eosinophils (non-eosinophilic inflam- 
mation) via the actions of Th1 chemokines. Recruited macrophages (M1 phenotype) produce mediators that inhibit the biologic activities of TGF- $\beta$, thereby enhancing AHR.

\section{Methods}

\section{Mice}

Lung-targeted IFN- $\gamma$ TG mice and their littermate WT control mice on the BALB/c background were generated as previously described (Wang et al., 2000) and maintained in the Yale University School of Medicine animal facility. $\mathrm{IL}-13^{-/-}$mice on the BALB/c background were generated in the laboratory of Andrew McKenzie, as described previously (McKenzie et al., 1998). IFN- $\gamma^{-1-}$ (BALB/c background), IL-12R $\beta^{2-1-}$ (C57BL/6), STAT4 ${ }^{-/-}$(BALB/C), IL-4 ${ }^{-/-}$ (BALB/C), IL-4R $\alpha^{-/-}$(BALB/C), and WT control (C57BL/6 and $B A L B / C$ backgrounds) mice were purchased from Jackson Laboratories (Bar Harbor). These mice were bred in pathogen-free facilities at Pohang University Science and Technology (POSTECH) and Yale University School of Medicine. All methods and protocols involving mice were approved by the Animal Care and Use Committee of POSTECH and Yale University School of Medicine.

\section{A murine model of Th2 type allergic asthma}

LPS-depleted OVA (Sigma-Aldrich) as an allergen was prepared as previously described (Eisenbarth et al., 2002). The generation of the Th2 type asthma mouse model has been described previously (Jeon et al., 2007a). Briefly, 6 -week-old mice were sensitized by intraperitoneal injection of $75 \mu \mathrm{g}$ OVA plus $2 \mathrm{mg}$ aluminum hydroxide (Sigma-Aldrich) or PBS on Days 0 and 7. Subsequently, these mice were challenged by intranasal administration of $50 \mu \mathrm{g}$ OVA on Days 14, 15, 21, and 22. Evaluations of methacholine AHR and pulmonary inflammation were performed $24 \mathrm{~h}$ and $48 \mathrm{~h}$ after the final allergen challenge, respectively. The T-cell responses were evaluated $6 \mathrm{~h}$ after allergen challenge on Day 21.

\section{Evaluations of methacholine AHR and lung inflammation}

Pulmonary function testing was assessed in conscious, unrestrained mice using noninvasive whole-body plethysmography (Allmedicus), as previously described (Jeon et al., 2007a). Lung and BAL samples were obtained as previously described (Jeon et al., 2007a). The total numbers of inflammatory cells were assessed after dilution of the cell pellets with $50 \mu$ PBS. After Diff-Quick staining (Dade Behring) of the BAL pellets in cytospin preparations, the inflammatory cells (macrophages, lymphocytes, neutrophils, or eosinophils) were classified by counting 300 cells. The lung was perfused with cold PBS through the right ventricle until the pulmonary vasculature was clean. The whole lung was inflated with fixatives for histology. Hematoxylin and eosin (H\&E) staining of lung sections was performed after pressure fixation with Streck solution
(Streck Laboratories). The same magnification was used for viewing the sample slides under the microscope, to allow comparisons.

\section{FACS analysis and intracellular cytokine staining}

For cell surface marker analysis, single-cell suspensions from the lung were prepared as described previously (Kim et al., 2007). Briefly, cells isolated from lung tissue $(4 \times$ $10^{6} / \mathrm{ml}$ ) were incubated in 48-well plates that were coated with anti-CD3 and anti-CD28 antibodies $(1 \mu \mathrm{g} / \mathrm{ml}$ each; eBioscience, San Diego, CA) at $37^{\circ} \mathrm{C}$ for $6 \mathrm{~h}$, and then restimulated with brefeldin $A(10 \mu \mathrm{g} / \mathrm{ml})$ for $2 \mathrm{~h}$. Cells were stained with surface-specific antibodies (anti-CD3-APC, anti-CD4-FITC, anti-CD8-PE-Cy5, and anti-CD11b-FITC; $\mathrm{BD}$ Biosciences) for $30 \mathrm{~min}$ at $4^{\circ} \mathrm{C}$, and then fixed for 10 min in $4 \%$ paraformaldehyde at room temperature. Cells were incubated with anti-IFN- $\gamma$-PE (BD Biosciences) for 30 min at room temperature, and analyzed on a FACScalibur flow cytometer (BD Biosciences) using the CellQuest software.

\section{Serum antibody levels}

The serum OVA-specific IgG2a and IgE levels were determined as previously described (Kim et al., 2007). Briefly, ELISA plates coated with OVA $(10 \mu \mathrm{g} / \mathrm{ml}$ in carbonate-bicarbonate buffer; Sigma-Aldrich) were incubated overnight at room temperature. Appropriately diluted serum samples were incubated for $2 \mathrm{~h}$ at room temperature in plates that were blocked with $3 \%$ skim milk (Sigma-Aldrich). Biotinylated anti-mouse $\operatorname{lgE}$ and $\operatorname{lgG} 2 \mathrm{a}$ antibodies (BD Biosciences) were added, and the plates were incubated for $2 \mathrm{~h}$ at room temperature. Streptavidin-horseradish peroxidase (BD Biosciences) was added and the substrate step was performed in accordance with the manufacturer's instructions (BD Biosciences).

\section{Quantification of cytokines in BAL fluids}

The levels of IFN- $\gamma$, IP- 10, IL-12, TGF- $\beta 1$, and IL- 13 in the BAL fluids were measured by ELISA, in accordance with the manufacturer's instructions (R\&D Systems).

\section{Statistical analysis}

Significant differences between the treatments were assessed using the Student's t-test, ANOVA or Wilcoxon's rank-sums test. For multiple comparisons, ANOVA was used initially, and when significant differences were found, individual $t$-tests or Wilcoxon's rank-sums tests for pairs of groups were performed.

\section{Acknowledgements}

We thank Jee-In Lim for providing secretarial assistance, and members of POSTECH animal facility for their helping with the animal experiments. This study was supported by grants from the Korea Ministry of Health and Welfare, Republic of Korea (A080711-0912-0000100). 


\section{References}

Aman MJ, Tayebi N, Obiri NI, Puri RK, Modi WS, Leonard WJ. cDNA cloning and characterization of the human interleukin 13 receptor alpha chain. J Biol Chem 1996;271:29265-70

Caput D, Laurent P, Kaghad M, Lelias JM, Lefort S, Vita N, Ferrara $P$. Cloning and characterization of a specific interleukin (IL)-13 binding protein structurally related to the IL-5 receptor alpha chain. J Biol Chem 1996;271:16921-6

Cohn L, Homer RJ, Marinov A, Rankin J, Bottomly K. Induction of airway mucus production By T helper 2 (Th2) cells: a critical role for interleukin 4 in cell recruitment but not mucus production. J Exp Med 1997;186:1737-47

Cohn L, Tepper JS, Bottomly K. IL-4-independent induction of airway hyperresponsiveness by Th2, but not Th1, cells. J Immunol 1998;161:3813-6

Colotta F, Orlando S, Fadlon EJ, Sozzani S, Matteucci C, Mantovani A. Chemoattractants induce rapid release of the interleukin 1 type II decoy receptor in human polymorphonuclear cells. J Exp Med 1995;181:2181-6

Donaldson DD, Whitters MJ, Fitz LJ, Neben TY, Finnerty H, Henderson SL, O'Hara RM Jr, Beier DR, Turner KJ, Wood $\mathrm{CR}$, Collins M. The murine IL-13 receptor alpha 2: molecular cloning, characterization, and comparison with murine IL-13 receptor alpha 1. J Immunol 1998;161:2317-24

Eisenbarth SC, Piggott DA, Huleatt JW, Visintin I, Herrick CA, Bottomly K. Lipopolysaccharide-enhanced, toll-like receptor 4-dependent $T$ helper cell type 2 responses to inhaled antigen. J Exp Med 2002;196:1645-51

Gavett SH, O'Hearn DJ, Li X, Huang SK, Finkelman FD, Wills-Karp M. Interleukin 12 inhibits antigen-induced airway hyperresponsiveness, inflammation, and Th2 cytokine expression in mice. J Exp Med 1995;182:1527-36

Hargreave FE, Dolovich J, O'Byrne PM, Ramsdale EH, Daniel EE. The origin of airway hyperresponsiveness. $J$ Allergy Clin Immunol 1986;78:825-32

Hilton DJ, Zhang JG, Metcalf D, Alexander WS, Nicola NA, Willson TA. Cloning and characterization of a binding subunit of the interleukin 13 receptor that is also a component of the interleukin 4 receptor. Proc Natl Acad Sci USA 1996;93: 497-501

Hogan SP, Matthaei KI, Young JM, Koskinen A, Young IG, Foster PS. A novel T cell-regulated mechanism modulating allergen-induced airways hyperreactivity in BALB/c mice independently of IL-4 and IL-5. J Immunol 1998;161:1501-9

Iwamoto I, Nakajima H, Endo H, Yoshida S. Interferon $\gamma$ regulates antigen-induced eosinophil recruitment into the mouse airways by inhibiting the infiltration of CD4+ T cells. J Exp Med 1993;177:573-6

Jeon SG, Lee CG, Oh MH, Chun EY, Gho YS, Cho SH, Kim $\mathrm{JH}$, Min KU, Kim YY, Kim YK, Elias JA. Recombinant basic fibroblast growth factor inhibits the airway hyperresponsiveness, mucus production, and lung inflammation induced by an allergen challenge. J Allergy Clin Immunol 2007a; 119:831-7

Jeon SG, Oh SY, Park HK, Kim YS, Shim EJ, Lee HS, Oh MH,
Bang B, Chun EY, Kim SH, Gho YS, Zhu Z, Kim YY, Kim YK. $\mathrm{TH} 2$ and $\mathrm{TH} 1$ lung inflammation induced by airway allergen sensitization with low and high doses of double-stranded RNA. J Allergy Clin Immunol 2007b;120:803-12

Kim YK, Oh SY, Jeon SG, Park HW, Lee SY, Chun EY, Bang B, Lee HS, Oh MH, Kim YS, Kim JH, Gho YS, Cho SH, Min KU, Kim YY, Zhu Z. Airway Exposure Levels of Lipopolysaccharide Determine Type 1 versus Type 2 Experimental Asthma. J Immunol 2007;178:5375-82

Kuipers H, Hijdra D, De Vries VC, Hammad H, Prins JB, Coyle AJ, Hoogsteden HC, Lambrecht BN. Lipopolysaccharideinduced suppression of airway Th2 responses does not require IL-12 production by dendritic cells. J Immunol 2003 171:3645-54

Lee CG, Homer RJ, Zhu Z, Lanone S, Wang X, Koteliansky V, Shipley JM, Gotwals P, Noble P, Chen Q, Senior RM, Elias JA. Interleukin-13 induces tissue fibrosis by selectively stimulating and activating transforming growth factor beta(1). J Exp Med 2001;194:809-21

McKenzie GJ, Bancroft A, Grencis RK, McKenzie AN. A distinct role for interleukin-13 in Th2-cell-mediated immune responses. Curr Biol 1998;8:339-42

Morishima Y, Nomura A, Uchida Y, Noguchi Y, Sakamoto T, Ishii Y, Goto Y, Masuyama K, Zhang MJ, Hirano K, Mochizuki M, Ohtsuka M, Sekizawa K. Triggering the induction of myofibroblast and fibrogenesis by airway epithelial shedding. Am J Respir Cell Mol Biol 2001;24:1-11

Murata T, Obiri NI, Puri RK. Structure of and signal transduction through interleukin-4 and interleukin-13 receptors (review). Int J Mol Med 1998a;1:551-7

Murata T, Taguchi J, Puri RK. Interleukin-13 receptor alpha' but not alpha chain: a functional component of interleukin-4 receptors. Blood 1998b;91:3884-91

Neurath MF, Finotto S, Glimcher LH. The role of Th1/Th2 polarization in mucosal immunity. Nat Med 2002;8:567-73

Pueringer RJ, Hunninghake GW. Inflammation and airway reactivity in asthma. Am J Med 1992;92:32S-8S

Rankin JA, Picarella DE, Geba GP, Temann UA, Prasad B, DiCosmo B, Tarallo A, Stripp B, Whitsett J, Flavell RA. Phenotypic and physiologic characterization of transgenic mice expressing interleukin 4 in the lung: lymphocytic and eosinophilic inflammation without airway hyperreactivity. Proc Natl Acad Sci USA 1996;93:7821-5

Robinson DS, Hamid Q, Ying S, Tsicopoulos A, Barkans J, Bentley AM, Corrigan C, Durham SR, Kay AB. Predominant TH2-like bronchoalveolar T-lymphocyte population in atopic asthma. N Engl J Med 1992;326:298-304

Robinson D, Hamid Q, Bentley A, Ying S, Kay AB, Durham SR. Activation of CD4+ T cells, increased TH2-type cytokine mRNA expression, and eosinophil recruitment in bronchoalveolar lavage after allergen inhalation challenge in patients with atopic asthma. J Allergy Clin Immunol 1993;92:313-24

Szabo SJ, Sullivan BM, Peng SL, Glimcher LH. Molecular mechanisms regulating Th1 immune responses. Annu Rev Immunol 2003;21:713-58

Vignola AM, Chanez P, Chiappara G, Merendino A, Pace E, 
Rizzo A, la Rocca AM, Bellia V, Bonsignore G, Bousquet J. Transforming growth factor-beta expression in mucosal biopsies in asthma and chronic bronchitis. Am J Respir Crit Care Med 1997;156:591-9

Wang Z, Zheng T, Zhu Z, Homer RJ, Riese RJ, Chapman HA, Jr., Shapiro SD, Elias JA. Interferon gamma induction of pulmonary emphysema in the adult murine lung. $J$ Exp Med 2000;192:1587-600

Weinberger SE. Recent advances in pulmonary medicine (1). N Engl J Med 1993;328:1389-97

Whyte MK, Choudry NB, Ind PW. Bronchial hyperresponsiveness in patients recovering from acute severe asthma. Respir Med 1993;87:29-35

Wills-Karp M, Luyimbazi J, Xu X, Schofield B, Neben TY, Karp CL, Donaldson DD. Interleukin-13: central mediator of allergic asthma. Science 1998;282:2258-61

Wills-Karp M. Immunologic basis of antigen-induced airway hyperresponsiveness. Annu Rev Immunol 1999;17:255-81

Wood N, Whitters MJ, Jacobson BA, Witek J, Sypek JP,
Kasaian M, Eppihimer MJ, Unger M, Tanaka T, Goldman SJ, Collins M, Donaldson DD, Grusby MJ. Enhanced interleukin (IL)-13 responses in mice lacking IL-13 receptor alpha 2 . J Exp Med 2003;197:703-9

Zhang JG, Hilton DJ, Willson TA, McFarlane C, Roberts BA, Moritz RL, Simpson RJ, Alexander WS, Metcalf D, Nicola NA. Identification, purification, and characterization of a soluble interleukin (IL)-13-binding protein. Evidence that it is distinct from the cloned II-13 receptor and II-4 receptor alpha-chains. J Biol Chem 1997;272:9474-80

Zhu Z, Homer RJ, Wang Z, Chen Q, Geba GP, Wang J, Zhang $Y$, Elias JA. Pulmonary expression of interleukin- 13 causes inflammation, mucus hypersecretion, subepithelial fibrosis, physiologic abnormalities, and eotaxin production. J Clin Invest 1999;103:779-88

Zurawski SM, Vega F Jr, Huyghe B, Zurawski G. Receptors for interleukin-13 and interleukin-4 are complex and share a novel component that functions in signal transduction. EMBO J 1993;12:2663-70 